\title{
PENINGKATAN KOMPETENSI GURU BIOLOGI MELALUI PELATIHAN PENGGUNAAN APLIKASI BIOINFORMATIKA
}

\section{IMPROVING BIOLOGY TEACHER COMPETENCY THROUGH TRAINING USE OF BIOINFORMATIC APPLICATIONS}

\author{
RD Pratiwi'1a, RH Pratiwi ${ }^{1}$, dan $S$ Noer ${ }^{1}$ \\ 1 Program Studi Pendidikan Biologi, Universitas Indraprasta PGRI Jakarta \\ a Korespondensi: Rosa Dewi Pratiwi, Email: tewe_chemist@yahoo.co.id atau shafa_noer@yahoo.co.id
}

(Diterima: 14-09-2017; Ditelaah: 14-09-2017; Disetujui: 28-10-2017)

\begin{abstract}
The purpose of bioinformatics training for Biology teachers in DKI Jakarta, especially in East and South Jakarta was to improve the competence of biology teachers in technology, information and computer. The implementation of Bioinformatics training was held twice on face-to-face meeting on 8 and 15 August 2017. The training lasted for 8 hours for one-to-one meeting which was held at 08.30-16.30 WIB, held in hall of SMA N 39 East Jakarta. Materials given at first face-to-face was introductions related to Bioinformatics science, NCBI explanation, BLAST usage, Mega 7.0 application theory, and Chromas Pro. While on the second face-to-face, participants practice using Mega 7.0 and Chromas Pro applications. At the end of the face-to-face, evaluation (test form) was given to participant's learning. Based on the evaluation results from 40 participants, it could be stated that there are 5 participants categorized have less value, 18 participants are categorized enough, 15 participants good and 2 participants very good.
\end{abstract}

Keywords: bioinformatics, biology, teacher, BLAST, Chromas Pro

\begin{abstract}
ABSTRAK
Tujuan pelaksanaan pelatihan Bioinformatika untuk guru-guru Biologi di DKI Jakarta khususnya di Jakarta Timur dan Selatan adalah meningkatkan kompetensi guru biologi dalam bidang teknologi, informasi dan komputer. Pelaksanaan pelatihan Bioinformatika dilaksanakan sebanyak dua kali tatap muka yaitu pada tanggal 8 dan 15 Agustus 2017. Pelatihan berlangsung selama 8 jam untuk sekali tatap muka yaitu pada pukul 08.30-16.30 WIB, bertempat di aula SMA N 39 Jakarta Timur. Materi yang diberikan pada tatap muka pertama adalah pengenalan terkait ilmu Bioinformatika, penjelasan NCBI, penggunaan BLAST, teori aplikasi Mega 7.0, dan Chromas Pro. Sedangkan pada tatap muka kedua, peserta berlatih menggunakan aplikasi Mega 7.0 dan Chromas Pro. Pada akhir tatap muka, tim pelaksana pelatihan mengadakan evaluasi berupa test untuk mengetahui ketercapaian belajar peserta. Berdasarkan hasil evaluasi dari 40 peserta, maka dapat dinyatakan bahwa ada 5 peserta dikategorikan memiliki nilai kurang, 18 peserta dikategorikan cukup, 15 peserta baik dan 2 peserta sangat baik.

Kata kunci: bioinformatika, biologi, guru, BLAST, Chromas Pro.
\end{abstract}

Pratiwi RD, RH Pratiwi, dan S Noer. 2017. Peningkatan kompentensi guru biologi melalui pelatihan penggunaan aplikasi bioinformatika. Qardhul Hasan: Media Pengabdian kepada Masyarakat 3(2): 153- 160. 


\section{PENDAHULUAN}

Saat ini banyak upaya peningkatan mutu pendidikan terus dilakukan oleh berbagai pihak. Upaya-upaya tersebut dilandasi suatu kesadaran betapa pentingnya peranan pendidikan dalam pengembangan sumber daya manusia dan pengembangan watak bangsa (Nation Character Building) untuk kemajuan masyarakat dan bangsa (Ismail, 2008).

Harkat dan martabat suatu bangsa sangat ditentukan oleh kualitas pendidikannya. Keberhasilan suatu pendidikan terkait dengan masalah pencapaian keberhasilan dalam proses belajar mengajar. Menurut Belinda dan Tse-Kiang (2007) salah satu komponen yang penting dalam keberhasilan proses belajar mengajar adalah sumber belajar yang mencakup sumber belajar yang dirancang (learning resources by designed) dan sumber belajar yang yang dimanfaatkan (learning resources by utilization).

Saat ini, media pembelajaran sebagai salah satu sumber belajar siswa telah tersentuh dampak perkembangan teknologi. Dapat dikatakan bahwa, hari ini siswa lebih berpengalaman di bidang Informasi dan Teknologi dibandingkan guru-gurunya, terutama internet, jaringan, dan aplikasi komputer atau software. Melihat perkembangan fenomena tersebut, dunia pendidikan khususnya guru sebagai fasilitator yang tidak dapat mengoptimalkan teknologi informasi dalam pembelajaran, maka akan tertinggal. Oleh karena itu, sudah saatnya guru dan siswa memanfaatkan software yang mendukung proses pembelajaran khususnya untuk mata pelajaran biologi.

Biologi adalah kajian tentang kehidupan, organisme hidup, termasuk struktur, fungsi, pertumbuhan, evolusi, persebaran, dan taksonominya (Yudiarti, 2010). Oleh karena itu, untuk mempelajari biologi dibutuhkan sumber belajar berupa software seperti bioinformatika, BLAST, Mega, Chromas Pro, Chemoffice, dan BioChem atau media yang dapat mempermudah siswa memahami materi yang sedang dipelajari. $\begin{array}{ccc}\text { Bioinformatika } & \text { adalah ilmu } \\ \text { mempelajari } & \text { penerapang }\end{array}$ komputasional untuk mengelola dan menganalisis informasi biologi. Bidang ini mencakup penerapan metode-metode matematika, statistika, dan informatika untuk memecahkan masalah-masalah biologis, terutama dengan menggunakan sekuens DNA dan asam amino serta informasi yang berkaitan dengannya. Contoh topik utama bidang ini meliputi basis data untuk mengelola informasi biologi, penyejajaran sekuens (sequence alignment), prediksi struktur untuk meramalkan bentuk struktur protein maupun struktur sekunder RNA, analisis filogenetik, dan analisis ekspresi gen.

Istilah bioinformatics sebenarnya mulai dikemukakan pada pertengahan era 1980an untuk mengacu pada penerapan komputer dalam biologi. Namun, penerapan bidang-bidang dalam bioinformatika (seperti pembuatan basis data dan pengembangan algoritma untuk analisis sekuens/ DNA biologis) sudah dilakukan sejak tahun 1960-an.

Kemajuan teknik biologi khusus molekular dalam mengungkap sekuens biologis dari protein dan asam nukleat sejak tahun 1960-an mengawali perkembangan basis data dan teknik analisis sekuens biologis. Basis data sekuens protein mulai dikembangkan pada tahun 1960-an di Amerika Serikat, sementara basis data sekuens DNA dikembangkan pada akhir 1970-an di Jerman dan Amerika (pada European Molecular Biology Laboratory, Laboratorium Biologi Molekular Eropa). Penemuan teknik sekuensing DNA yang lebih cepat pada pertengahan 1970-an menjadi landasan terjadinya ledakan jumlah sekuens DNA yang berhasil diungkapkan pada 1980an dan 1990-an, menjadi salah satu pembuka jalan bagi proyek-proyek pengungkapan genom, meningkatkan kebutuhan akan pengelolaan dan analisis sekuens, dan pada akhirnya menyebabkan lahirnya bioinformatika. Selain itu, 
perkembangan teknologi sangat mendukung ilmu bioinformatika.

Basis data bioinformatika yang terhubung melalui internet memudahkan ilmuwan mengumpulkan hasil sekuensing ke dalam basis data tersebut maupun memperoleh sekuens biologis sebagai bahan analisis. Selain itu, penyebaran program-program aplikasi bioinformatika melalui internet memudahkan ilmuwan mengakses programprogram tersebut dan kemudian memudahkan pengembangannya.

Sesuai dengan jenis informasi biologis yang disimpannya, basis data sekuens biologis dapat berupa basis data primer untuk menyimpan sekuens primer asam nukleat maupun protein, basis data sekunder untuk menyimpan motif sekuens protein, dan basis data struktur untuk menyimpan data struktur protein maupun asam nukleat.

Basis data utama untuk sekuens asam nukleat/ DNA saat ini adalah Gen Bank dari Amerika Serikat, EMBL dari Eropa, dan DDBJ dari Inggris. Ketiga basis data tersebut bekerja sama dan bertukar data secara harian untuk menjaga keluasan cakupan masing-masing basis data.

BLAST (Basic Local Alignment Search Tool) merupakan perkakas bioinformatika yang berkaitan erat dengan penggunaan basis data sekuens biologis. Penelusuran BLAST (BLAST search) pada basis data sekuens memungkinkan ilmuwan untuk mencari sekuens asam nukleat maupun protein yang mirip dengan sekuens tertentu yang dimilikinya. sebagai koordinat tiga dimensi yang menggambarkan posisi atomatom dalam protein ataupun asam nukleat (Mount, 2001).

Berdasarkan wawancara tim pelaksana pelatihan dengan ketua Sanggar Biologi DKI Jakarta bahwa guru-guru biologi di DKI Jakarta belum sepenuhnya memanfaatkan software biologi dalam kegiatan belajar mengajar. Guru cenderung masih menggunakan buku dan belum pernah menggunakan aplikasi/software biologi dalam proses pembelajaran. Hal ini disebabkan karena guru-guru biologi belum menguasai bahkan belum mengetahui adanya software biologi yang mendukung proses pembelajaran.

Dari uraian diatas, tim pelaksana memandang perlunya dilakukan pelatihan dan pendampingan penguasaan software bioinformatika untuk seluruh guru-guru biologi di DKI Jakarta khususnya Jakarta Selatan dan Timur. Pemilihan dua wilayah ini ditentukan oleh ketua Sanggar Biologi 1 di DKI Jakarta. Kegiatan pelatihan bioinformatika ini bertujuan untuk meningkatkan kualitas kompetensi profesional guru biologi sehingga proses dan hasil belajar biologi siswa semakin baik.

\section{MATERI DAN METODE}

\section{Waktu dan Tempat Pelatihan}

Pelatihan software Bioinformatika dilaksanakan pada tanggal 8 dan 15 Agustus 2017 di aula SMA N 39 Jakarta, beralamat di Jl. RA Fadillah, Baru, Pasar Rebo, Jakarta Timur.

\section{Metode Pelatihan}

Kegiatan pelatihan Bioinformatika mencakup beberapa metode, yaitu sebagai berikut.

1. Ceramah disampaikan oleh narasumber untuk memaparkan materi bioinformatika yang sebelumnya belum dikenal oleh peserta.

2. Pre-test dan Post-test digunakan sebagai assesment untuk mengukur kemampuan peserta pelatihan terhadap materi yang akan dipelajari maupun setelah dipelajari.

3. Metode tanya jawab berlangsung saat penyampaian materi atau selama penggunaan aplikasi bioinformatika yang mencakup Mega 7.0 dan Chromas Pro.

4. Praktik langsung menggunakan software bioinformatika yang terdiri dari dua aplikasi yaitu Chromas Pro/ Bioedit dan Mega 7.0. 
5. Evaluasi hasil pelatihan yang dilaksanakan di bagian akhir setiap tatap muka.

\section{Evaluasi Keberhasilan Pelatihan}

Tingkat keberhasilan kegiatan ini dilakukan melalui penilaian setiap peserta yaitu nilai post-test dan pengamatan saat pelatihan berlangsung. Soal pre-test dan post-test sama sehingga dapat dibandingkan apakah ada perubahan sebelum dan sesudah pelaksanaan kegiatan. Soal pre-test dan posttest berupa soal uraian yang berisi 7 pertanyaan. Pertanyaan yang diajukan adalah: 1) Apakah yang dimaksud dengan bioinformatika? 2) Apa sajakah yang dipelajari di bioinformatika? 3) Apa yang dimaksud dengan ekspresi gen?, 4) Apa sajakah sumber data base literatur untuk bioinformatika? 5) Apa yang dimaksud dengan homologi? 6) Apa yang Anda ketahui tentang sekuen? dan 7) Bagaimana cara menentukan spesies dari dari organisme atau mikroorganisme yang Anda temukan? Sedangkan untuk penilaian terhadap keberhasilan setiap peserta dikategorikan menurut pedoman yang tertera dalam tabel 1. Hasil post test peserta yang berupa nilai akan dibandingkan dengan hasil pre-test yang sebelumnya telah dilakukan. Analisis terhadap hasil pretest dan post test peserta dilakukan menggunakan statistik sederhana.

Tabel 1 Pedoman Penilaian

\begin{tabular}{lll}
\hline No & Rentangan Nilai & Kategori \\
\hline 1 & $85-100$ & Sangat Baik \\
2 & $70-84$ & Baik \\
3 & $55-69$ & Cukup \\
4 & $<54$ & Kurang \\
\hline
\end{tabular}

\section{HASIL DAN PEMBAHASAN}

Pelaksanan pengabdian kepada masyarakat yang dilakukan oleh tim pelaksana dengan mitra guru-guru Biologi yang tergabung dalam Sanggar Biologi 1 DKI Jakarta dapat dikatakan berlangsung dengan baik. Kegiatan pelatihan software bioinformatika dilaksanakan tanggal 8 dan 15 Agustus 2017 bertempat di Aula SMA N 39 Jakarta. Sasaran atau peserta pelatihan melibatkan dua mitra yaitu guru-guru yang tergabung dalam sanggar MGMP Biologi 1 di Jakarta yang beranggotakan guru-guru Biologi SMA di Jakarta Timur dan Jakarta Selatan. Pelatihan ini diikuti oleh guru-guru Biologi SMA baik SMA negeri maupun swasta di Jakarta Timur dan Jakarta Selatan. Peserta pelatihan software Bioinformatika terdiri dari 20 guru Biologi SMA di Jakarta Selatan dan 20 guru Biologi SMA di Jakarta Timur.

Pelatihan tanggal 8 Agustus dimulai sejak pukul 07.00 WIB dengan agenda pengisian biodata peserta kemudian jam 08.00 WIB peserta mengikuti pre-test yang dipandu oleh Dr. Rina Hidayati Pratiwi. Soal Pre-test dikerjakan pada lembar jawab selama 15 menit. Pada sesi pre-test ini masih ada 30\% peserta yang belum datang. Akhirnya, sesi ini berlangsung sampai jam 09.00 WIB yang seharusnya sudah selesai jam 08.15 WIB.

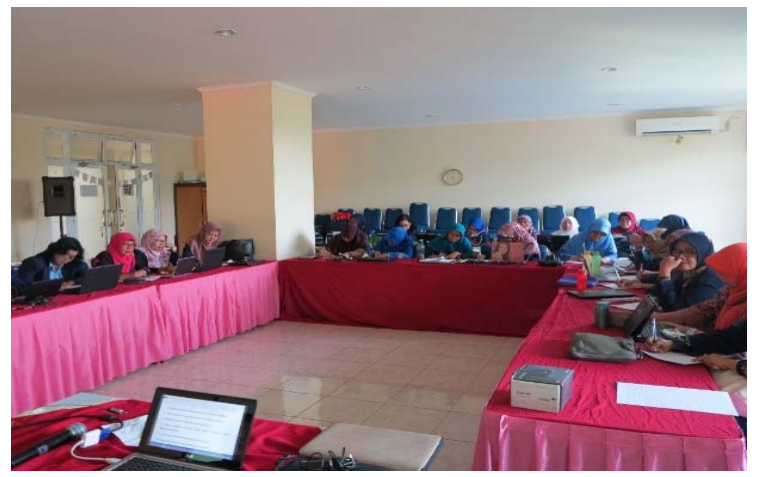

Gambar 1 Peserta mengerjakan pre-test

Pada sesi ini, ada peserta yang memanfaatkan handphone nya untuk browsing mencari jawaban lewat internet. Tim pelaksana langsung menegur peserta yang tidak mematuhi tata tertib dalam mengerjakan pre-test. Bagi peserta yang datang terlambat durasi pre-test tidak ditambah yaitu tetap 15 menit. Setelah pretest selesai, tim pelaksana menarik jawaban dari peserta. Dari 36 peserta yang hadir, ada 4 orang peserta yang tidak mengerjakan pretest dikarenakan peserta tersebut datang sangat terlambat atau melewati pukul 08.45 WIB. 
Hasil evaluai pre-test yang dilaksanakan, ternyata hanya ada 5 peserta dari 40 peserta yang mendapatkan nilai lebih dari 54 . Artinya soal pre-test tersebut dianggap sukar oleh peserta yang notabene mereka adalah guru Biologi. Sesi selanjutnya adalah penyampaian materi yang dipandu oleh $\mathrm{Dr}$. Rina Hidayati Pratiwi. Materi yang akan dipaparkan sudah dimiliki oleh peserta. Peserta mendengarkan sambil menyimak materi yang sudah ada di laptop masingmasing. Pada sesi ini terlihat peserta merasa asing dengan materi yang disampaikan.

Materi bioinformatika ternyata belum pernah dipelajari sebelumnya. Selama 30 menit penyampaian materi, tim pelaksana membuka termin tanya jawab untuk peserta. Berdasarkan pengamatan kami, ada 6 peserta yang mengajukan pertanyaan. Pertanyaan yang muncul adalah 1) Bagaimana kita bisa menerapkan bioinformatika ini untuk siswa? 2) Apa yang dimaksud dengan NCBI? 3) Bagaimana keterkaitan bioinformatika dengan materi genetika pada kelas XII SMA? 4) Fungsi bioinformatika dalam pembelajaran? 5) Apa yang dimaksud kueri? dan 6) Dimana letak mRNA dan DNA?

Begitu banyak pertanyaan yang muncul. Kuantitas dan kualitas pertanyaan dari peserta, membuat tim mengetahui bahwa mereka sama sekali belum mengerti materi yang disampaikan. Akhirnya tanya jawab sampai jam 10.15 WIB dan panitia meminta agar peserta mengambil teh hangat dan roti agar suasana menjadi cair dan pikiran tenang kembali. Materi bioinformatika dianggap terlalu tinggi oleh peserta, sehingga harus benar-benar dijelaskan dengan detail satu per satu istilah yang mereka belum tahu. Sesi tanya jawab diakhiri sampai jam 11.00 WIB.

Sesi selanjutnya adalah praktik langsung menggunakan aplikasi Basic Local Alignment Searching Tool (BLAST) yang dipandu oleh Shafa Noer, M.Si. Tim pelaksana meminta peserta untuk menyiapkan modem atau wifi yang sudah terpasang di setiap laptop masing-masing. Peserta diminta membuka alamat web http://www.ncbi.nih.gov. Shafa
Noer, memandu bagaimana menggunakan alamat web ini untuk mencari sekuens setiap spesies. Peserta diminta mengisikan nama spesies dalam bahasa latin dalam kolom search yang tertera pada web ncbi. Peserta diminta mengetik "Zea mays" pada kolom search.

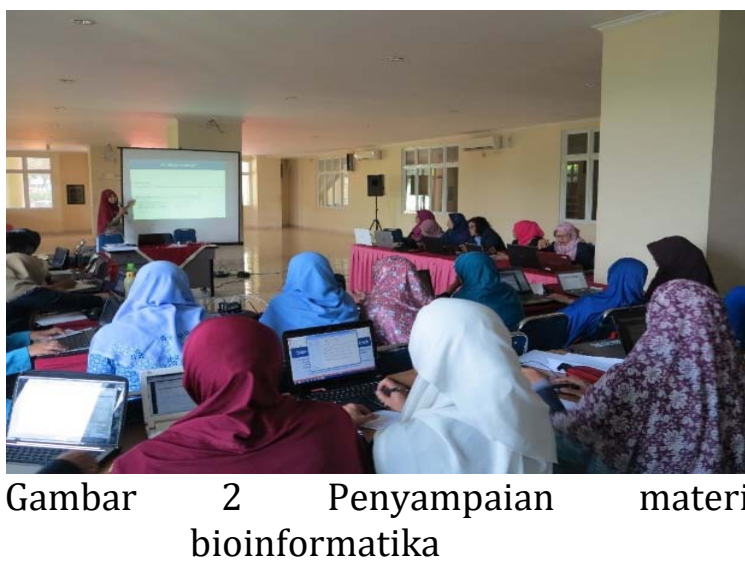

Pada langkah ini, ternyata banyak kendala yang di temui oleh tim pelaksana. Beberapa kendala yang terjadi antara lain: 1) ada beberapa peserta yang laptopnya tidak bisa terkoneksi dengan internet, 2) ada pula laptop yang sudah bisa membuka alamat web yang diminta tetapi tidak bisa digunakan untuk belajar dikarenakan ikonikon pada halaman web tidak bisa dibuka, 3) faktor usia peserta yang sudah lanjut, sehingga peserta ketinggalan mengikuti instruksi dari pelatih. Kendala ini alhamdulillah bisa ditangani dengan cara peserta yang muda dan tidak gagap teknologi IT membantu peserta yang lebih tua atau cenderung gagap mengoperasikan laptopnya.

Setelah semua terkondisikan dengan penampilan di layar laptop sama, maka instruktur Shafa Noer, mulai menjelaskan fungsi tools -tools yang ada di halaman muka web tersebut. Dengan penjelasan yang lugas, peserta memahami apa yang disampaikan oleh pelatih. Sama dengan saat sesi pertama penyampaian materi, tim membuka sesi tanya jawab kembali. Ada 4 peserta yang bertanya dengan pertanyaan yang berbeda. Pertanyaan yang muncul adalah 1) Mengapa ketika kita mengetik Zea mays dengan ejaan huruf yang berbeda (ada yang mengetik Zea 
mais ada yang mengetik Zea mays) keluarnya sama? 2) Bagaimana kita bisa tahu sekuen dari suatu spesies? Carinya dimana? 3) Bagaimana kita bisa melihat ada berapa penelitian yang sudah membahas tentang Zea mays? dan 4) Apa fungsi masing-masing dari BLAST Nukleotida dan BLAST protein?

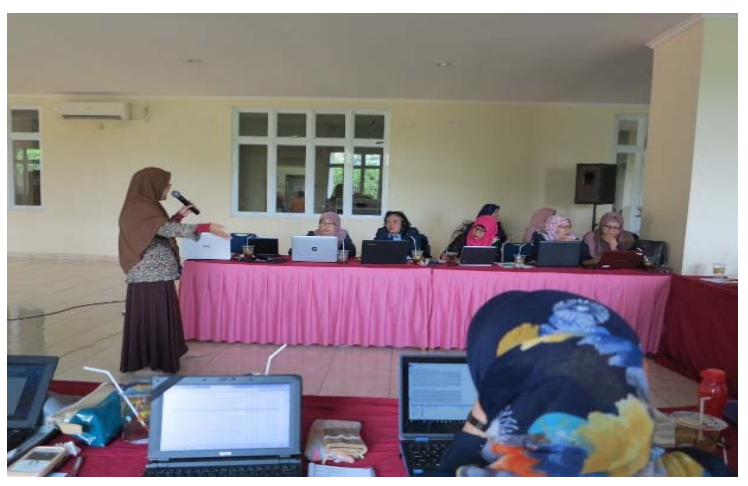

Gambar 3 Sesi praktik aplikasi BLAST

Beberapa pertanyaan diatas dijawab dan dijelaskan oleh tim pelaksana. Jawaban untuk pertanyaan pertama adalah BLAST memiliki keunggulan yaitu bisa mendeteksi bahasa latin yang ingin kita maksudkan walaupun penulisannya kurang atau tidak sempurna. Pertanyaan kedua dijelaskan oleh Dr. Rina Hidayati Pratiwi yaitu sekuen setiap spesies bisa kita lihat sekuennya dengan melihat tampilan BLAST (Basic Local Alignment Searching Tool) icon FASTA. Icon FASTA kita klik lalu akan muncul sekuen dalam notepad kita. Jawaban ketiga adalah kita menggunakan icon yang ada disebelah kiri yang bertuliskan Nucleotida. Ketika kita klik Nukelotida maka akan muncul ada berapa penelitian yang bisa kita jadikan referensi. Jawaban atas pertanyaan keempat yaitu BLAST Nukleotida dikhususkan untuk analisis sekuen dari suatu DNA sedangkan BLAST protein untuk menganalisis sekuen suatu protein. Paparan dari instruktur termyata bisa dipahami oleh peserta.

Menjelang pukul 12.00 WIB, panitia meminta peserta untuk makan, istirahat dan sholat bagi yang beragama Islam dan mengingatkan kembali bahwa jam 13.00 WIB peserta harus sudah di Aula kembali. Pukul 13.00 WIB, peserta kembali menerima paparan dari instruktur mengenai studi homologi. Homologi yang dimaksud disini adalah homologi genetik. Materi yang disampaikan selama 90 menit diterima baik oleh peserta. Kadang disela-sela paparan, peserta ada yang mengajukan pertanyaan. Sesi materi ketiga ini selesai jam 15.00 WIB. Kemudian acara dilanjutkan dengan posttest.

Post-test dilaksanakan di setiap akhir tatap muka pelatihan. Post-test yang diberikan mengukur sejauh mana peserta menangkap materi yang telah disampaikan khususnya materi BLAST yang nantinya bisa langsung dipraktikan ke siswa saat proses kegiatan belajar mengajar. Peserta diminta mencari sekuens DNA dari padi kemudian memindahkan sekuens tersebut ke dalam notepad. Waktu post-test dibatasi hanya 20 menit. Pada sesi ini tim pelaksana/ pelatih mencermati siapa yang benar-benar bisa mandiri mengerjakan dan ada yang tidak. Hanya ada 7 peserta yang bisa mengerjakan sendiri tugas tersebut dan tepat waktu. Selebihnya tim pelaksana mendampingi untuk ikut memandu mengerjakan post-test tersebut. Penghujung acara pelatihan Bioinformatika pada tatap muka 1 ini diakhiri dengan penutupan dari ketua Sanggar Biologi 1 DKI Jakarta, dan dilanjutkan dengan foto bersama serta bersalaman. Sebelum acara selesai, ada beberapa peserta yang meminta ijin untuk kembali ke sekolah jam 15.00 WIB dengan alasan agenda rapat.

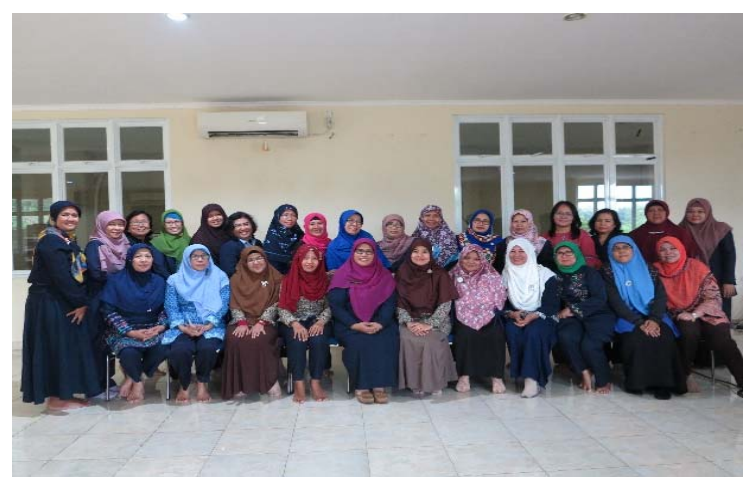

Gambar 4 Sesi foto bersama

Tatap muka kedua untuk pelatihan Bioinformatika yaitu pada hari Selasa tanggal 15 Agustus 2017 bertempat di aula SMA N 39 Jakarta. Jumlah peserta yang hadir 
adalah 40. Dari 40 peserta yang hadir, hanya ada 1 peserta laki-laki. Mayoritas peserta adalah ibu-ibu guru biologi SMA di DKI Jakarta. Jadwal kegiatan pada tatap muka kedua adalah mempraktikan penggunaan aplikasi Mega 7,0 dan Chromas Pro sehingga didapatkan pohon phylogeny.

Pada pukul 08.00 WIB peserta yang diundang belum sepenuhnya hadir, namun dari panitia sudah memulai membuka acara pelatihan. Tepat pukul 08.30 WIB, sesi I dimulai dengan pelatihan penggunaan Chromas Pro. Sesi I ini dipandu oleh Dr. Rina Hidayati Pratiwi, M,Si. Sesi I ini berlangsung selama 2,5 jam. Pelatih menjelaskan langkahlangkah menggunakan aplikasi Mega 7,0 dengan pemaparan yang pertama adalah cara menjajarkan sekuen. Sebelumnya, peserta sudah menerima file mengenai sekuens DNA yang akan digunakan saat belajar Chromas Pro. Peserta dengan mudah mengakses file tersebut karena sudah ada di laptop masing-masing.

Pada pemaparan kedua, pelatih menjelaskan cara memotong sekuens, mengapa kita harus memotong sekuens, dan merapikan sekuen dengan baik. Sesi ini adalah sesi yang menarik bagi peserta. Selain peserta bisa fokus pada pengerjaannya sendiri, peserta juga banyak melontarkan pertanyaan.

Tujuan penggunaan Mega 7.0 dan Chromas Pro adalah ingin mengetahui hubungan kekerabatan dari beberapa spesies yang ingin kita ketahui melalui pohon phylogeny. Pohon phylogeny didapatkan setelah kita mendapatkan beberapa sekuen dari 10 spesies yang pada sesi sebelumnya sudah kita cari dan simpan sekuens tersebut adalam note pad. Hasil penjajaran sekuen DNA dari suatu spesies yang dilakukan menggunakan aplikasi Chromas Pro.

Pemaparan selanjutnya adalah penggunaan aplikasi Mega 7.0. yang dimulai setelah makan siang dan sholat dhuhur. Paparan ini masih dijelaskan oleh Dr. Rina Hidayati Pratiwi. sampai menghasilkan pohon phylogeny. Tata cara menggunakan aplikasi Chromas Pro dan Mega 7.0 telah tertulis dalam modul bioinformatika yang sudah dibagikan ke peserta sebelum tatap muka pertama dilaksanakan.

Penggunaan aplikasi Mega 7.0 dinilai oleh peserta lebih mudah ketimbang aplikasi Chromas Pro. Pada aplikasi ini, peserta cukup mendengarkan atau melihat langkahlangkah pada modul. Hasil akhir yang didapatkan setelah menggnakan aplikasi Mega 7.0 adalah pohon phylogeny. Pelatih menjelaskan makna dari pohon phylogeny tersebut, bagaimana hubungan kekerabatan dari beberapa spesies dan bagaimana bisa membandingkan hubungan kekerabatan antara satu spesies dengan spesies lainnya dalam satu pohon. Penjelasan pohon phylogeny sangat ditunggu-tunggu peserta. Hal itu disebabkan karena peserta sebagai guru dan pelatih OSN (Olimpiade SAINS Nasional) di sekolah sering menjumpai soal mengenai pohon phylogeny. Guru-guru ternyata masih belum tahu bagaimana menjelaskan hubungan kekebratan dari beberapa spesies dengan melihat pohon phylogeny yang selama ini disajikan pada soal OSN.

Pada sesi ini banyak sekali pertanyaan yang muncul. Diantaranya yaitu: 1) apa makna angka pada pohon phylogeny? 2) Apa makna panjang pendek pada ranting pohon phylogeny? 3) apa makna skala pada pohon phylogeny?

Jawaban dari tiga pertanyaan diatas dapat dijelaskan dengan baik oleh pelatih sehingga peserta benar-benar memahami pohon phylogeny yang selama ini belum diketahui. Akhir pertemuan pada tatap muka kedua ini adalah test/ ujian untuk peserta. Tim pelaksana ingin mengevaluasi sampai dimana penguasaan materi aplikasi khususnya Mega 7.0 dan Chromas Pro. Tim pelatih menghimbau agar peserta yang belum menguasai materi bioinformatika untuk belajar secara berkelompok dengan teman yang sudah mampu. Hasil analisis test terhadap penguasaan materi bioinformatika disajikan pada tabel 2 .

Setelah mendapatkan hasil evaluasi dari post test yang dilakukan, tim pelaksana mencoba membandingkan hasil evaluasi dari 
peserta pelatihan yang terdiri dari dua kelompok yaitu guru-guru SMA yang berada di wilayah Jakarta Selatan dan Jakarta Timur. Rerata hasil post- test guru-guru Biologi SMA di Jakarta Selatan lebih baik dibandingkan guru-guru Biologi SMA di Jakarta Timur. Hal ini kemungkinan disebabkan oleh usia peserta. Guru-guru SMA yang mengikuti pelatihan dengan usia diatas 50 ada 6 peserta di Jakarta Timur yang mungkin kemudian menghambat kinerjanya dalam mengerjakan post test ataupun saat latihan.

Tabel 2 Distribusi penilaian peserta pelatihan

\begin{tabular}{lllr}
\hline No & $\begin{array}{c}\text { Rentangan } \\
\text { Nilai }\end{array}$ & Kategori & $\begin{array}{r}\text { Jumlah } \\
\text { Peserta }\end{array}$ \\
\hline 1 & $85-100$ & Sangat Baik & 2 \\
2 & $70-84$ & Baik & 15 \\
3 & $55-69$ & Cukup & 18 \\
4 & $<54$ & Kurang & 5 \\
\hline
\end{tabular}

\section{KESIMPULAN DAN IMPLIKASI}

Pelaksanaan pelatihan Bioinformatika untuk guru-guru SMA Biologi di Jakarta Timur dan Selatan yang tergabung dalam Sanggar Biologi 1 DKI Jakarta dapat dinyatakan berhasil. Beberapa hal yang dapat disimpulkan dari hasil pelaksanaan kegiatan ini, antara lain sebagai berikut.

1. Semua guru/ peserta memahami materi Bioinformatika. Hal ini terlihat dari hasil post-test yaitu $87,5 \%$ peserta masuk dalam kategori cukup/ baik.

2. Semua guru/ peserta mengerjakan soal latihan yang terdapat dalam modul.
3. Semua guru/ peserta sangat antusias. Hal ini ditunjukkan dengan berbagai pertanyaan yang diajukan saat pelatihan.

4. Hasil diskusi tim pelaksana dengan pihak mitra (guru-guru biologi SMA dalam Sanggar Biologi 1 DKI Jakarta), diharapkan adanya pelatihan aplikasi biologi lanjutan secara kontinu yang sesuai dengan kebutuhan proses belajar mengajar biologi sehingga materi yang diperoleh dapat dikuasai secara mendalam dan menyeluruh.

\section{DAFTAR PUSTAKA}

Depdiknas. 2013. Penilaian Afektif. Jakarta: kemendikbud.

Ismail Feiby. 2008. Solusi Peningkatan Kualitas Pendidikan. Jurnal Pendidikan vol 5 Januari-Juni. Diakses tanggal 23 April 2017.

Mount, D.W. 2001. Bioinformatics. Sequence and Genome Analysis, Cold Spring Harbor: Cold Spring Harbor Laboratory Press, ISBN 0-87969-608-7. Diakses dari Wikipedia.org. 10 Maret 2017.

Soo-Phing TEOH Belinda dan Tse-Kian NEO. 2007. Interactive Multimedia Learning: Student's Attitudes and Learning Impact in an Animation Course. Malaysia: Centre for Innovative Education (CINE), Faculty of Creative Multimedia, Multimedia University. The Tourkish Journal of Educational Technology. ISSN; 1303-6521 Volume 6 Issue 4 Article 3. http://www. ejmste.com. Volume 3 (35-39). Diakses tanggal 13 April 2017.

Yudiarti, Turrini. 2010. Buku Ajar Biologi. Semarang: UNDIP Press. 